American Journal of Environmental Sciences 6 (4): 395-401, 2010

ISSN 1553-345X

(C) 2010 Science Publications

\title{
Impact of Mercury Mine Activities on Water Resources at Azzaba-North-East of Algeria
}

\author{
Fadila Alligui and Abdelhak Boutaleb \\ Department of Geology, University of Sciences and Technology, \\ Houari Boumediene, Algiers-Algeria
}

\begin{abstract}
Problem statement: Mercury mineralization occurred in Azzaba (north-eastern Algeria) as a part of mercurial Numidian belt, consists of numerous of $\mathrm{Hg}$ deposits (Koudiat Sma, Mrasma, Guenicha, Fendek, Ismail and Ras Elma). These deposits are hosted in a variety of lithologies including sandstone, limestone, breccias and conglomerate. The ores occur as cinnabar deposits in Ypresian-Lutetian formations. Although the quantity and type of information relating to mining operations within Azzaba remains insufficient and sparse an assessment of the impacts that mining and processing activities, have had or are likely to have, on water resources is required to describe the evidence of the origin and the extent Approach: 17 ground water samples were collected at different locations within the $\mathrm{Hg}$ mineralized area and analyzed to assess the source, degree and extent of the contamination. Results: The primary effect of mining is degradation of tens of kilometers of disturbed streams, thousands hectares of disturbed land including valuable ecosystems. chemical analysis showed that ground waters were also adversely affected by pollutants loading, the alluvial aquifer (composed primarily of silty sand and gravel) that serves as the primary source of drinking water for Menzel Ben Dishe, Es-sebt and Zaouia communities surrounding Ismail mercury complex shows high concentrations of $\mathrm{Hg}$ and other heavy metals. Conclusion: These high values were associated and controlled by mixed origin with similar contribution from anthropogenic and geoginic sources.
\end{abstract}

Key words: Mercury, mineralization, lithologies, Ypresian-Lutetian, Numidian sequence

\section{INTRODUCTION}

Mercury discharged from its generation source, through dispersion, causes a wide pollution of environment. Numerous studies have concluded that mercury is the most highly bio-accumulated toxic trace element in the human food chain; therefore it has been the focus of research activities for the last fifty years.

Mercury is not only hazardous to human health and the environment but could also attack equipment components resulting in a mechanical failure and gas leakage (Kamarudin and Mohamad, 2010).

It occurs naturally and exists under several states. Such a property requires a deep knowledge of metal speciation not only for understanding mechanisms of transport, chemical reactions and transformation of the metal in the subsurface but also because it can be a pollutant with harmful physiological effects.

The levels of mercury can be raised naturally either by the weathering of mineralized rocks or by dispersion from anthropogenic sources. Once mercury has been liberated from its sources and released into environment, it can be highly mobile, cycling between earth's surface, water and atmosphere. Mercury can enter the atmosphere as a gas or bound to others airborne particles. Atmospheric transport is likely the primary mechanism by which $\mathrm{Hg}$ is distributed throughout the environment. In addition to atmospheric pathways, mercury can be transported through river systems in their sediment loads, or in aqueous solution. Soil mercury pollution can be a major chronic pollution hazard. Most of the sites are historical industrial ones. In many areas, the soil pollution may be of geological origin rather than a result of human activity. Mercury may also introduce into groundwater as result of dissolution and oxidation of ore deposit or by the weathering of tailing containing high levels of $\mathrm{Hg}$. Consequently understanding of physical chemical and biological processes responsible of mobilization and fate of mercury, is required to predict its impact on human health as well as ecosystems.

Corresponding Author: Fadila Alligui, Department of Geology, University of Sciences and Technology, Houari Boumediene, Algiers-Algeria 


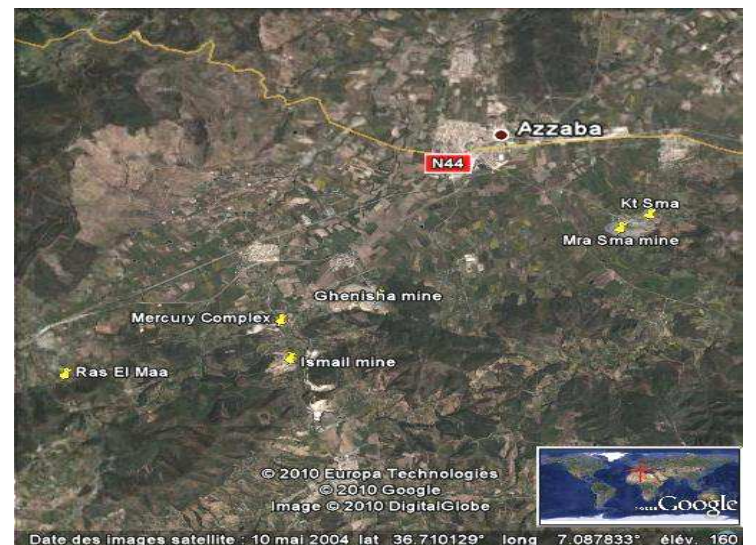

Fig. 1: Location map of study area

Mercury mineralization occurs in Azzaba-northeastern Algeria-as numerous of $\mathrm{Hg}$ deposits localities in Koudiat Sma, Mrasma, Guenicha, Fendek, Ismail and Ras Elma (Fig. 1). This mineralization has been recognized from roman epoch, residues of cinnabar extraction have been discovered, at Grayer as a part of the north Numidian belt which was a subject of several investigations, in 1853; mercury has been identified at Ras El Ma deposit and has been extracted during over a century. In 1966, National Society of Mining Research (NSMR) started its prospection over the Numidian sequences of Azzaba where were delineated in 1969 the most important ore deposits. In 1970, Ismail mercurial complex was installed by ENOF (National Corporation of Non-Ferrous Mining Products and Useful Materials) and has been the important supplier of mercury during over thirty years. Capacity of Azzaba mines exploited by the complex was around 7,000-8,000 flasks (200$230 \mathrm{t}^{\text {year }^{-1}}$ ), it rose to 23,000 flasks in 1984 but remained below its peak of 31,000 flasks reached in 1970. The production have been stopped during the second half of 2003 for a few months in order to rehabilitate the equipment of the mine and complex, as well as the reinforcement of mining work with a view to restarting production in January 2005. The mines were continually being flooded by an underground river that pumping has proved unsuccessful, also local residents have long complained of environmental problems and diseases linked to the mines. Consequently closure of the complex has been officially announced on May 2006.

\section{MATERIALS AND METHODS}

Topography: Numidian belt outcrops, surrounding Azzaba basin form low ranges or lines of residual low mountains and hills controlled by structure (bedding, folds and faults).

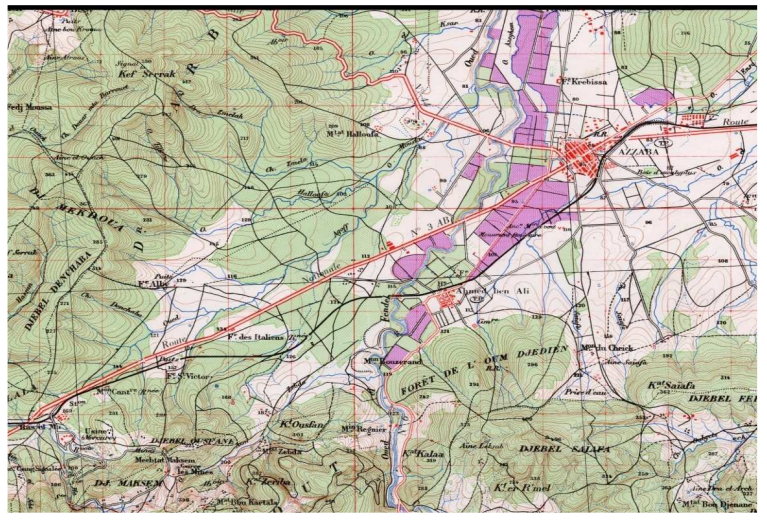

Fig. 2: Topographic map of the study area

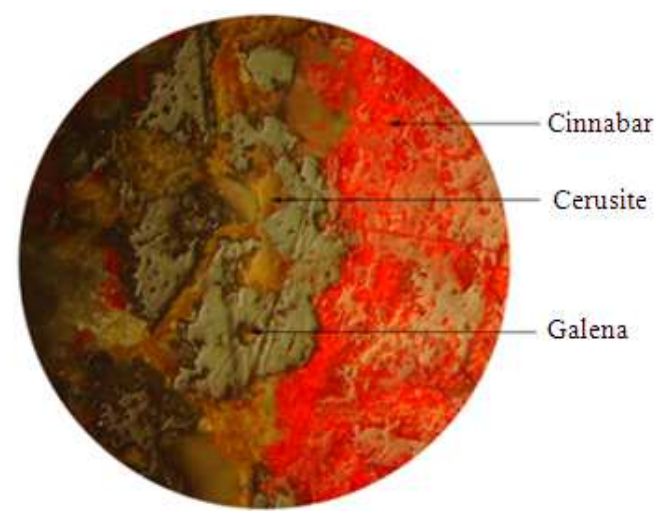

Fig. 3: Cinnabar cerusite and galena association

Generally, Azzaba topography is made up of SW$\mathrm{NE}$ and E-W trending hill series and mountains i.e., Djebel Haloufa (Kef Serrak) 530 m, Djebel Mekdona 414, Djebel Sayafa 496 m, Djebel Regouat Lassouad $432 \mathrm{~m}$ and Djebel Chebbik 447. The slope varies from 12-25\%. Sma hill $334 \mathrm{~m}$, Mra Sma hill $372 \mathrm{~m}$ and Guenicha hill where were extracted the principal mercury ores occupied the central part of Azzaba plains and drained by Fendek River tributaries. The hill series in each of these areas is separated by narrow tracts of plains. All hill series and plains run almost parallel, a characteristic feature indicating that the topography has been controlled to a large extent by the geological factors of folding, faulting and lithology (Fig. 2).

Geology: Distribution of epithermal mercury and polymetallic As- $\mathrm{Hg}-\mathrm{Sb}-\mathrm{Pb}-\mathrm{Zn}$ deposits in north of Algeria are closely related to the orientations of the great regional structures. These deposits are hosted in a variety of Ypresian-Lutetian lithologies including sandstone, limestone, breccias and conglomerate; Much more common ores of mercuric sulfide, with cinnabar 
and metacinnabar, in association with other sulfide minerals as pyrite, galena, sphalerite, chalcopyrite, arsenopyrite (Fig. 3).

Alterations minerals such covellite, cerusite, iron oxides and hydroxides, sulfur and native mercury are also found in the mineralogical composition of almost ore deposits. The gangue minerals are quartz, calcite, dolomite, kaolin, organic matter and rarely barite. Disseminated and brecciaed ore textures of cinnabar and pyrite occur essentially in sandstones, conglomeratic breccias and occasionally in limestone. Cinnabar occurred also, in the vicinity of major faults as small veins crosscutting carbonate-hosted mercury rocks, the veins show open space filling textures (Fig. 4).

Structure: The general tectonostratigraphic framework of the area includes several units; the Numidian sequence represents one of the main tectonostratigraphic units involved in the geological evolution of the Maghrebian orogen during the Upper OligoceneLower Miocene (Moretti et al., 1991). An additional set of allochthonous units corresponding to deep-sea turbidity deposits are known as the Mauretanian and Massylian flyschs located at the southern edge of the Calcareous chain and the sedimentary sequences of the Tellian chain (Fig. 5). The faults are characterized by strike slip and dip-slip components of displacement. These fault systems trend roughly NW, NE and EW. Thrust sheets are mapped in numerous localities in Azzaba, Kabylian thrust oriented E-W; Where Paleozoic schists have been impressed over Neocomian and Campanian formations in certain localities, in others they overlap Lutetian-Priabonian formations. Ismail thrust overlies carbonates with argillaceous schist's. Following the thrust faulting, broad uplift and folding took place. Although Ypresian-Lutetian formations were affected by folds with different dimensions from one to several meters tricking NNWSSE and dipping strongly to the southwest and the west. The same structures are found in the LutetianPreabonian formations but with smallest dimensions falling southwest and west. Known mineral occurrences are associated with Ahmed Ben Ali E-W trending fault which limits the southern part of limits Azzaba (Bouarroudj, 1986; Bouaou and Diane, 1990; Mhidi and Younes, 2005; Vila, 1980).

Hydrogeology: Aquifers in the study area occur in three main water-bearing units: Paleocene-Eocene aquifer, the fractured Oligocene sandstone aquifer and the Quaternary alluvial aquifer. Most of which, have different characteristics and requirements for evaluation, management, vulnerability and exploitation.

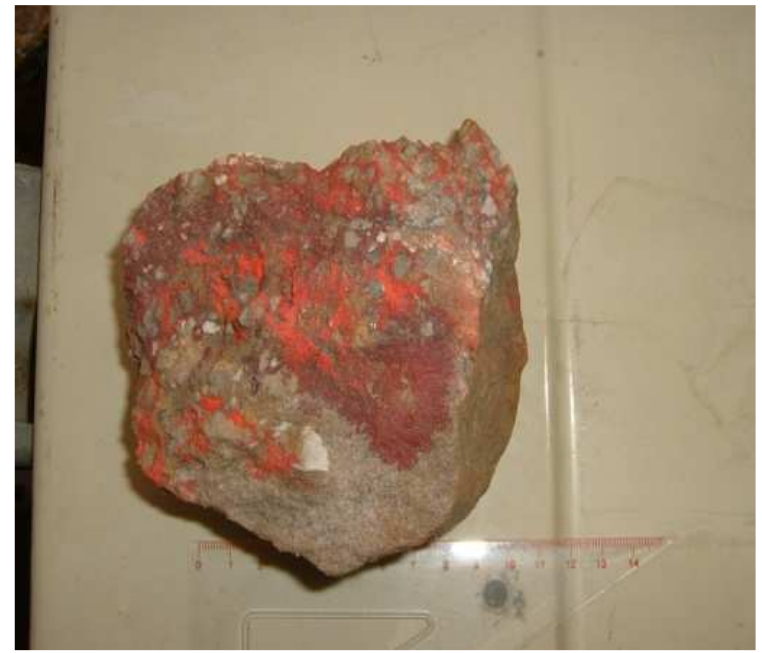

Fig. 4: Brecciaed ore texture

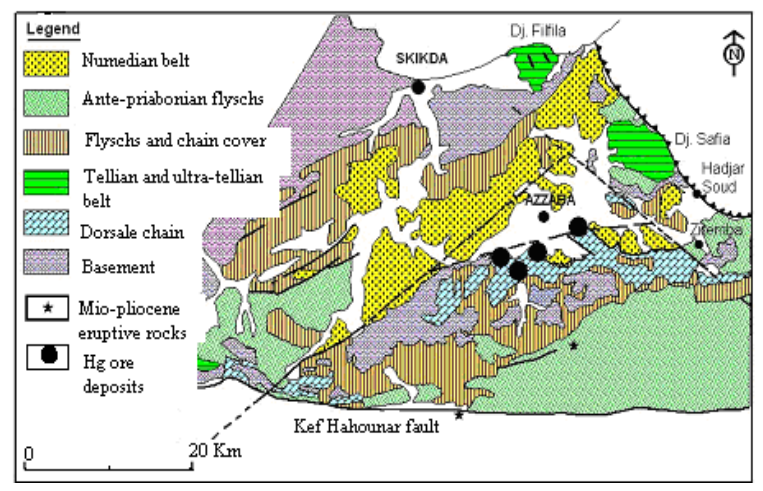

Fig. 5:Structural map of central and oriental Numedian belt (Vila, 1980; Bouarroudj, 1986)

The geologic structure in Azzaba Basin controls the occurrence, availability and movement of all groundwater. In general, groundwater in Azzaba moves northward and northeastward toward Fendek stream. This movement reflects the surface topography, structure and the general drainage pattern of the area. The geologic structure forces groundwater to flow through SE-NE synclinal surrounded by El Oust, Denchaba, Makdoua anticline limbs and the extensivefolded Numidian belt. potentiometric surface in quaternary aquifer is less than $90 \mathrm{~m}$ a.s.l eastward in vicinity of Azzaba town. The elevation increases to about $100 \mathrm{~m}$ a.s.l in the central part the groundwater flow direction shows regular sinuous pattern, its general trend is almost parallel to the river flow. The potentionmetric surface near Numidian hills ranges from more than $180-80 \mathrm{~m}$ a.s.l. The sinuous shape of the contours is result of groundwater recharge near the 
Numidian belt low-laying areas or discharge of Fendek stream. The water table lines show vertical contours northwest the study area intercepting the Oligocene Numedian impervious formations consist of argillaceous, marl and schist's (Fig. 6).

According to (Benhamza, 1996), similar pattern of movement is indicated in Oligocene complex and the Paleocene-Eocene complex. The elevation of the heads generally conforms to topography; higher heads occur in the higher altitude areas to the south; lower heads occur in the lower altitude areas to the north. Heads are higher in the deeper aquifers because their recharge areas are at a higher altitude. In the higher outcrops of aquifer, Paleocene-Eocene the potential exists for intraquifer groundwater movement from Paleocene-Eocene to Oligocene aquifer. At lower altitudes, the potential is reversed and water may move from Oligocene upward Paleocene-Eocene aquifer. Heads were generally near steady state except near mine area.

Impact of mine activities on natural hydrogeology:

Watershed: Three decades of mercury mining industry at Azzaba are responsible of tens of kilometers of disturbed streams, thousands hectares of disturbed land including valuable watershed ecosystems. Removing several hundred feet of a mountaintop to access a mercury ore vein is in itself destructive to the natural landscape. Although mine operators are required to return a disturbed environment to original contours, the laws of physics make it impossible to fully restore a mountain natural shape after so much material has been displaced. Regardless of the shape of the post-mining landscape, restoring natural vegetation and habitat is so difficult, yet the largest percentage of surface mines requiring valley fills.

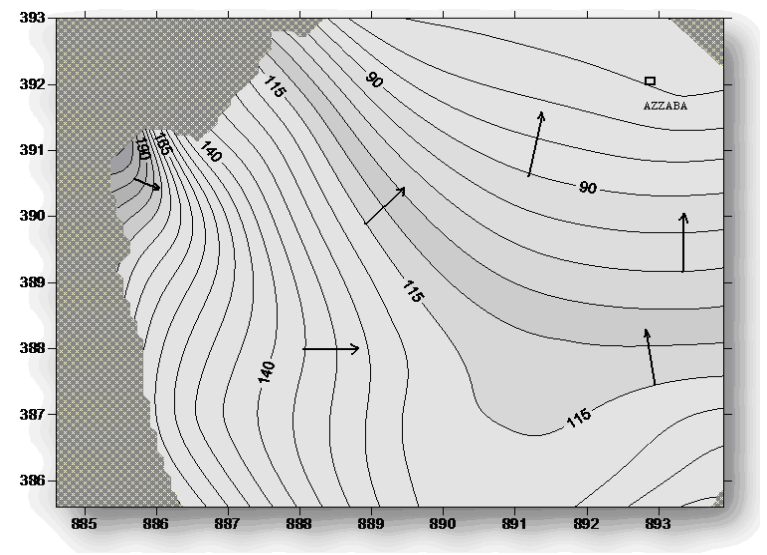

Fig. 6: Water table map of the study area 2009
Surface mining alters basic watershed characteristics such as area, slope and vegetative cover resulting in changes in runoff and infiltration. Stream flow system, especially during critical period such as peak flow, can be affected by alterations in channel geometry or gradient.

The known extent of mining impact on surface waters has been documented downstream to Fendek stream and the confluence with Radjita. Many of sites appear to have a serious effect on surface-water quality. Erosion, rainfall and leaching, transport mercury from land surfaces, tributaries that cut through mercury deposits mines contribute elevated amounts of mercury to the stream environment. Furthermore, during heavy rainfall contaminated process water of Ismail mercury complex is discharged through stream channels. This water contains a large amount of suspended $\mathrm{HgS}$ particles, metallic mercury and mercureous mercury $\mathrm{Hg}^{+2}$.

Relationships between mercury concentrations and watershed physiographic and morphometric characteristics was investigated and established. Results of analysis of Surface water samples collected at equal distances from mercury factory and diminishing altitude show a strong evidence of the influence of slope on mercury concentrations. The change in $\mathrm{Hg}$ concentrations with the change of slope is markedly different between upstream and downstream samples. The greater $\mathrm{Hg}$ levels were likely found in low-sloped watersheds of Fendek stream, while the lowest values were associated with relatively high-sloped ones (Benderradji, 1998).

Impact on groundwater: Where surface mine is excavated into aquifer materials, it clearly removes part of aquifer, which in itself may represent a loss of resource (increased of evaporation from the postmining pit-lake) or at least an increase in vulnerability for the surrounding aquifer (removal of the barrier to pollutant represented by the unsaturated zone). Beside this obvious impact a halo of increased permeability greater than background values can develop around open pit walls due to extensional fracturing induced by blasting and the lateral stresses. Indeed, permeability close to void may be so high as to favor turbulent flow near the void (Fig.7).

A further of pit lake left behind after ending of the surface mining is that the water table tends to be steeper on the up-gradient side of the pit and more gentle on the down-gradient side of the pit, than would be the case under natural conditions. On the other hand, although many pit lakes are in hydraulic continuity with the surrounding groundwater, in some cases the blinding of 
the pit floor with fine-grained sediments can effectively perch water in the open pit, with little or no interaction with the surrounding groundwater system.

Any excavation in a rock mass under the groundwater table tends to drain fluid from the rock. Fluid pressures, decrease to near-atmospheric levels in the excavation, which increases the hydraulic gradient. Drainage causes a reduction in water pressure near the excavation. However, this effect can be counteracted by seepage stresses (Fig. 8).

Sampling and analysis procedures: The fieldwork was conducted during July 2009, where 17 ground water samples were collected at different locations within the $\mathrm{Hg}$ mineralized area. The most important aspects according to the sampling protocol include the following:

- Clear pump before sampling to avoid any stagnant water in the pump system

- Pumping for $7 \mathrm{~min}$ is usually adequate

- Filter the sample through a $0.45 \mu \mathrm{m}$ filter

- Rinse the sampling bottle with groundwater before taking a sample

- Avoid mixing water with air at sampling

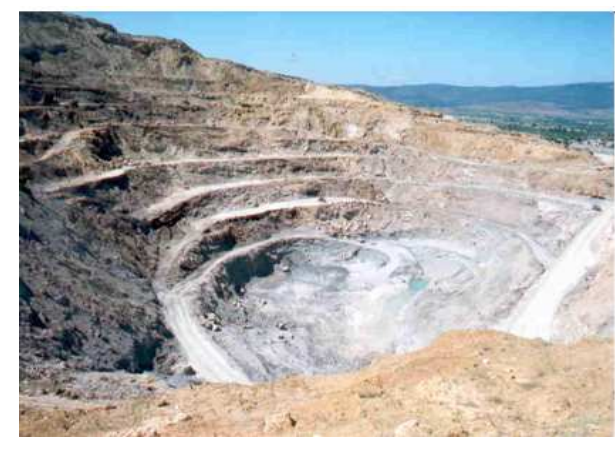

Fig. 7: Ghenicha mine before flooding (2004)

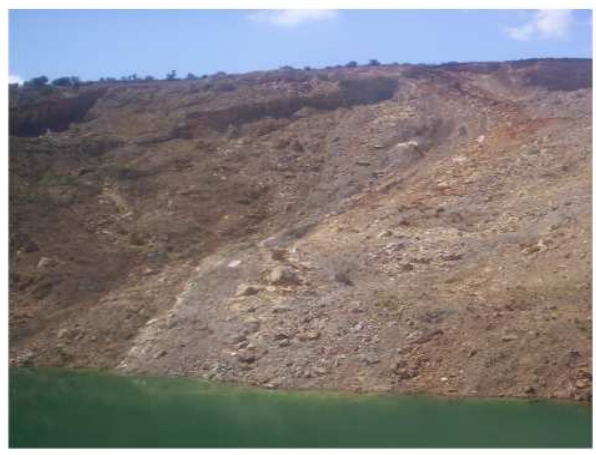

Fig. 8: Ghenicha mine after flooding (2007)
Each sample was collected in 1.51 plastic bottles for major element analysis and $100 \mathrm{ml}$ polyethylene bottles for trace element analysis where the $100 \mathrm{~mL}$ bottle was acidified with concentrated $\mathrm{HNO}_{3}$.

Major elements were performed at the Department of Geology at Constantine University Trace elements were analyzed at the National Hydraulic Resources Agency (NHRA) laboratory of Constantine. Acidified samples were used. Anions (bicarbonates, sulphates, chloride, nitrates) were determined by spectrophotometric, HPLC or volumetric methods and the main cations and trace elements were determined by ICPAES and/or FAAS methods. Total and calcic Hardness of the samples are determined by titration with the Ethylene-Diamine-Tetracetic-Acid (EDTA). The chlorides are determined by the method of Mohr and the sulfates by reading the absorbance with $\mathrm{A}=420 \mathrm{~nm}$ for suspension obtained by reaction of sulfates with barium chloride. Sodium and Potassium are dosed by photometry with flame emission.

\section{RESULTS}

The mean values of 17 samples from shallow aquifer groundwater are shown in (Table 1). Alkalinity in the ground water of Azzaba was $322.8 \mathrm{mg} \mathrm{L}^{-1}$ which exceeded the desirable limit in all well locations. The $\mathrm{pH}$ values fluctuated between 6.4 and 7.7.Chloride concentrations at or above $250 \mathrm{mg} \mathrm{L}^{-1}$. Lowest chloride levels are less than $20 \mathrm{mg} \mathrm{L}^{-1}$ and the highest levels of all unconsolidated aquifer system occur in the center of Azzaba plain. Sulfates were found to be in the range between $80-3200 \mathrm{mg} \mathrm{L}^{-1}$ during study. The chemical results show high $\mathrm{Hg}$ concentration values that exceed greatly the WHO recommended value, which is 0.001 $\mathrm{mg} \mathrm{L} \mathrm{L}^{-1}$. Different types of waters collected from shallow quaternary wells were defined; according to Piper classification (Fig. 9) waters have shown an evolution from Bicarbonate through mixed to sulfate.

Table 1: Summary of Azzaba shallow groundwater physicochemical analysis mean values

\begin{tabular}{lr}
\hline Parameters & Concentration $\left(\mathrm{mg} \mathrm{L}^{-1}\right)$ \\
\hline Dry residue & 1798.00 \\
Temperature $\left({ }^{\circ} \mathrm{C}\right)$ & 20.50 \\
$\mathrm{pH}$ & 7.00 \\
Conductivity $\left(\mu \mathrm{s} \mathrm{cm}^{-1}\right)$ & 2084.00 \\
Calcium & 144.20 \\
Magnesium & 71.30 \\
Sodium & 179.20 \\
Potassium & 7.90 \\
Chloride & 337.20 \\
Sulfate & 481.10 \\
Bicarbonate & 322.80 \\
Nitrate & 12.60 \\
Nitrite & 0.20 \\
Mercury & 0.16 \\
\hline
\end{tabular}




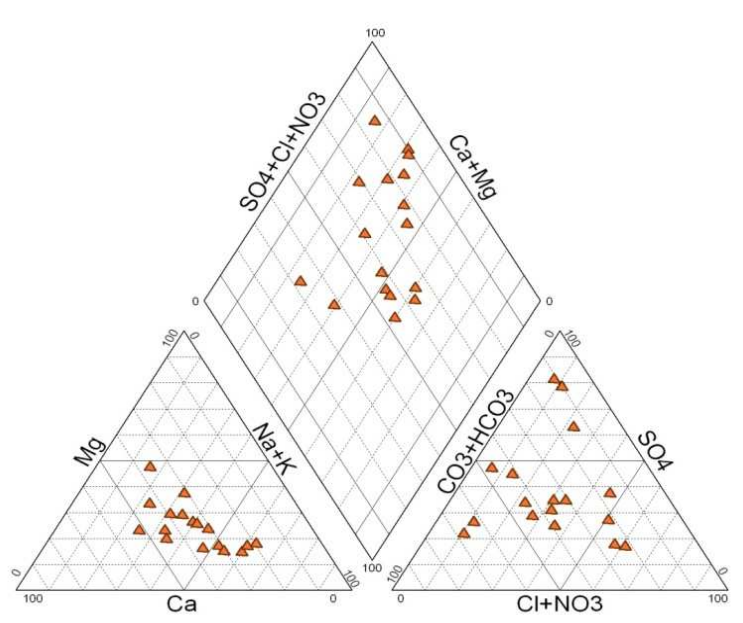

Fig. 9: Piper diagram of Azzaba shallow aquifer

The calcium bicarbonate facies characterizing the water of wells $\mathrm{N}^{\circ} 1$ and 2 located by the recharge area appears probably due to dissolution of carbonate minerals from brecciaed limestone and marl schist limestone of Lutetian. An intermediate facies occurs in wells $\mathrm{N}^{\circ} 3$, 8,6 and 15 showing a mixing character, the sodium chloride type characterize the wells $\mathrm{N}^{\circ} 7$ and 12 and the sulfite type appears in almost wells of the discharge area in the north-western part of Azzaba plain.

The sodium chloride facies occurs also in sandy and clayey reservoirs of Oligocene and the calcium sulfate one is located in the sandstones and clays of the Oligocene (Benhamza, 1996).

\section{DISCUTION}

The groundwater composition varies widely and is a combined result of the composition of the water entering the groundwater reservoir and the reactions with minerals present in the rock that may modify the water composition. Some minerals dissolve quickly and significantly change the water composition, like carbonates, others dissolve slowly and have less effect on the water composition, like silicates. The retention time is also important in determining the water chemistry. Long residence times allow reactions to take place and these waters are likely to have higher concentrations of ions than water with short residence times (Appelo and Postma, 2005).

The limit of $\mathrm{pH}$ value for drinking water is specified as 6.5-8.5. The $\mathrm{pH}$ shows slightly acidic trend in the mining location wells influenced by the generation of Acid mine drainage AMD. However in spite of the presence the AMD; Ghenisha open pit water shows $\mathrm{pH}$ value of 7.7 and this may result of the presence carbonate minerals witch increases buffering capacity of water. With halite rarely present in the geological sequence, the dominant natural source of chloride to recharge and groundwater flow is the contribution of sea-spray. Even if chloride is often an important dissolved constituent in ground water, five samples from superficial aquifer are classified as chloride dominated. Various geochemical processes, sources and time may influence the concentration of sulfate in ground water. One important source is the dissolution or weathering of sulfur-containing minerals. Two possible mineral sources of sulfate have been identified in the main aquifers of Azzaba. The first includes evaporate minerals, such as gypsum and anhydrite $\left(\mathrm{CaSO}_{4}\right)$. Gypsum and anhydrite are the two calcium sulfate minerals occurring in nature. The second possible mineral source of sulfate is the oxidation of mineral sulphurs present in YpresianLutetian Formations Such as pyrite $\left(\mathrm{FeS}_{2}\right)$, Sphalerite $\mathrm{ZnS}$, Arsenopyrite $\mathrm{FeS}_{2}$, FeAs, FeAsS, Chalcopyrite $\mathrm{CuFeS}_{2}$ and Galena $\mathrm{PbS}$, this is illustrated by the high concentration of the open pit lake water which reaches $830 \mathrm{mg} \mathrm{L}^{-1}$.

Although, cinnabar, the $\mathrm{Hg}$ source mineral has low solubility in its natural environment; the large range in mercury concentration is caused by several factors. The most important factors are the solubility of the mercury phases associated with the mine drainage, mercury speciation and soil properties. An interesting feature is that the geochemical background of the region reflects the elevated concentration of mercury, lead, copper and zinc in the sulfate groundwater. Mercury in the groundwater certainly originates from industrial and mine activities and from the oxidation of cinnabar and metacinnabar. Mercury that is released to surface soils is generally retained in the solid phase through adsorption onto sulfides, clay particles and organic matter (Evans, 1989; Moreno et al., 2005). These $\mathrm{Hg}$ forms are insoluble and therefore, relatively immobile. However, exchange reactions can occur in the soil solution, leading to increased $\mathrm{Hg}$ solubility and mobility in soil. Chloride $\left(\mathrm{Cl}^{-}\right.$and Hydroxide $\left(\mathrm{OH}^{-}\right)$ ions occur naturally in soils and the soluble $\mathrm{HgCl}_{2}, \mathrm{Hg}$ $(\mathrm{OH}) \mathrm{Cl}$ and $\mathrm{Hg}(\mathrm{OH})_{2}$ complexes are the predominant $\mathrm{Hg}$ species in well-oxygenated environments (Schuster, 1991; Moreno et al., 2005).

Variations in physicochemical conditions in the area surrounding mining environment influence the stability of metal sulfides which are currently a subject of strong weathering, resulting to a destabilization of $\mathrm{Hg}$ ores deposit, liberating $\mathrm{Hg}$ and heavy metals and consequently becoming a potential warning to the 
environment. The weathering of $\mathrm{Hg}$-bearing minerals in the mine and in the tailing, results in the transport of dissolved $\mathrm{Hg}$ into upper and underling aquifer.

\section{CONCLUSION}

Past industrial and mining activities has spread mining waste materials in the area of Azzaba, which can be considered an initiator of pollutant leaching that carries $\mathrm{Hg}$ and heavy metals from the mined area to soils and waters. Geochemical and mineralogical data from mine rocks suggest that cinnabar, metacinnabar, pyrite, arsenopyrite, galena and chalcopyrite are the main contributors to the high $\mathrm{Hg}, \mathrm{Pb}, \mathrm{Fe}$ and $\mathrm{Zn}$ contents found in waters downstream the mine works. The instability of these minerals abandoned in a humid environment and affected by surface waters, is increased by the weathering processes. These geochemical processes provide the production of metal rich leachates causing an obvious impact on the environment and promoting the generation of acid mine drainage, elevated concentrations of $\mathrm{Hg}$ in surface water, groundwater and soils. The proximity of the mine to an important urban area gives an additional factor of risk to the site, suggesting a need for the introduction of control measures to improve the environmental quality of streams in the catchment. This will require a detailed study focused on the identification and characterization of anthropogenic contamination originating from mining activities in the area and the behavior of pollutants and their behavior on environment and human health.

\section{ACKNOWLEDGEMENT}

The authors wish to thank the National Hydraulic Resources Agency (HNRA) laboratory for the Chemical analysis and for the technical support.

\section{REFERENCES}

Appelo, C.A.J. and D. Postma, 2005. Geochemistry, Groundwater and Pollution. 2nd Edn., Balkema, Rotterdam, Netherlands and Brookfield, Vermont, ISBN: 0415364280, pp: 649.

Benderradji, M.H., 1998. Interferences between Values of slope and Mercury specialization in Azzaba Depression (North-East of Algeria). University of Constantine.
Benhamza, M., 1996. Hydrogeological study of Fendek mercurial Area (Azzaba)-effect of mining on environment. M.Sc. Thesis, IST/UBM.

Bouaou, H. and B. Diane, 1990. Mercury deposit (Azzaba), geological and metallogenic study, mineralization-tectonic relationship. M.Sc. Thesis, IST/USTHB.

Bouarroudj, M.T., 1986. Metallogenic study of the nord-numidic mercurious belt (Azzaba District, North-East Algeria) control and perspectives researches. Ph.D. Thesis, Pierre and Marie Curie University.

Evans, L.J., 1989. Chemistry of metal retention by soils. Environ. Sci. Technol., 23: 1046-1056. DOI: 10.1021/es00067a001

Kamarudin, K.S.N. and M.F. Mohamad, 2010. Synthesis of gold $(\mathrm{Au})$ nanoparticles for mercury adsorption. Am. J. Applied Sci., 7: 835-839. DOI: $10.3844 / .2010 .835 .839$

Mhidi, R. and F. Younes, 2005. Contribution to geological and metallogenic study of ghenicha deposit, ismail mercuriel Zone (Azzaba) Skikda province. M.Sc. Thesis. FSTGAT/USTHB.

Moreno, F.N., C.W. Anderson, R.B. Stewart, B.H. Robinson and M. Ghomshei et al., 2005. Induced plant uptake and transport of mercury in the presence of sulphur-containing ligands and humic acid. New Phytol., 166: 445-454. PMID: 15819909

Moretti, E., R. Coccioni, F. Guerrera, J.C. Lahondère and F. Loiacono et al., 1991. The Numidian Sequence between Guelma and Constantine (Eastern Tell, Algeria). Terra Nova, 3: 153-165. DOI: $10.1111 /$ j.1365-3121.1991.tb00868.x

Schuster, E., 1991. The behavior of mercury in the soil with special emphasis on the complication and adsorption processes-a review of the literature. Water Air Soil Pollut., 56: 667-680. DOI: 10.1007/BF00342308

Vila, J.M., 1980. The alpine chain Of Eastern Algeria and the Algerian-Tunisien border. Ph.D. Thesis, Pierre and Marie Curie University. 